\title{
Blood glucose monitoring techniques: recent advances, challenges and future perspectives
}

\author{
Tadesse Waktola Gamessa ${ }^{1,3 *}$, Dabbu Suman ${ }^{2}$ and Zerihun Ketema Tadesse ${ }^{1,4}$ \\ Master of Engineering Graduate, Department of Biomedical Engineering, University College of Engineering (A), \\ Osmania University, Hyderabad, Telangana, India ${ }^{1}$ \\ Assistant Professor, Department of Biomedical Engineering, University College of Engineering (A), Osmania \\ University, Hyderabad, Telangana, India ${ }^{2}$ \\ Biomedical Engineer, Gandhi Memorial Hospital, Addis Ababa City Administration Health Bureau, Addis Ababa, \\ Ethiopia $^{3}$ \\ Biomedical Engineer, Yekatit 12 Hospital Medical College, Addis Ababa City Administration Health Bureau, Addis \\ Ababa, Ethiopia $^{4}$
}

\section{(C)2018 ACCENTS}

\begin{abstract}
Blood glucose monitor is a fundamental tool to maintain and control blood glucose levels for routine management of diabetes and complications associated with it. There have been continuous scientific advances and achievements in biosensors for the development of comprehensive glucose monitoring systems since last few decades. Portable, accurate, and reliable glucose monitoring devices with advanced features have been developed in recent years. However, invasive glucose monitors remained the most dominant devices on the market. Commercialization of clinically accurate and dependable non-invasive blood glucose monitoring devices still require rigorous works and further studies in sensor technologies. The aim of this article is to bring current updates and recent progress in electrochemical glucose sensing and non-invasive glucose monitoring techniques along with their merits and limitations. We present their key challenges and address future prospects of non-invasive glucose monitoring.
\end{abstract}

\section{Keywords}

Glucose, Electrochemical, Glucose monitoring, Non-invasive, Glucose monitors, Non-enzymatic.

\section{Introduction}

The recent scientific advancements in glucose sensing technologies have revolutionized the development and commercialization of glucose monitoring devices. With current technological improvements in glucose biosensors, accurate, comprehensive and integrated glucose monitors have been developed. However, the current available glucose monitoring devices rely on invasive monitoring techniques that require finger prick to withdraw blood samples which cause pain, inconvenience and prone to infections. Hence, there is a need to develop accurate and reliable noninvasive blood glucose monitor that improves convenience and comfort for people with diabetes.

Blood glucose monitoring techniques are broadly classified into invasive, minimally invasive and noninvasive based on their detection modality $[1,2]$ (as shown in Figure 1).

*Author for correspondence

335
Enzymatic electrochemical glucose sensors are the most utilized sensing techniques in the blood glucose monitoring [3, 4]. Through advances in nanotechnology and bio-sensing, the study of nonenzymatic electrochemical glucose sensors became of great interest [3]. Optical glucose sensing methods are among the widely studied non-invasive monitoring techniques to develop glucose monitors. The aim of this paper is to present and discuss the latest advances and developments in the blood glucose monitoring techniques. First, we briefly discuss the current advances in electrochemical blood glucose sensing in two categories: enzymatic and non-enzymatic electrochemical sensing techniques along with their advantages and limitations. Then, we present the recent progress in non-invasive blood glucose monitoring techniques with their merits and drawbacks. Finally, we will explain the key challenges of current blood glucose monitoring techniques and highlight their future perspectives focusing on non-invasive blood glucose monitoring. 


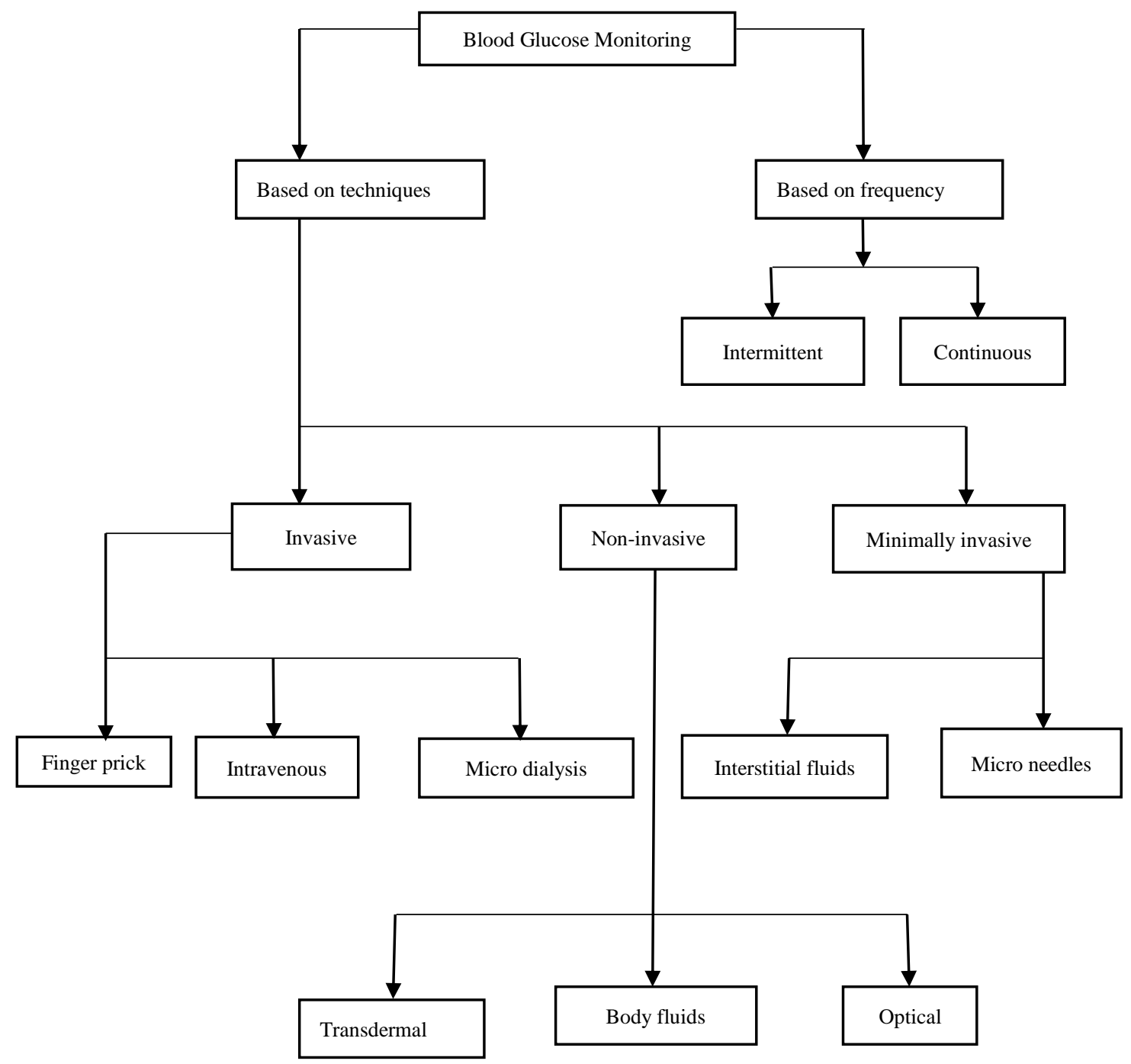

Figure 1 An overview of blood glucose monitoring techniques

\section{Invasive blood glucose monitoring techniques}

2.1Enzymatic electrochemical sensing

Electrochemical biosensors have revolutionized and dominated the markets of blood glucose monitoring devices since their evolution by Clark and Lyons in 1962. They were initially based on the glucose oxidase enzyme (GOx) for catalytic oxidation of glucose in the presence of oxygen that monitors consumption of oxygen or production of hydrogen peroxide [5, 6]. Electrochemical glucose sensors are the most utilized commercially available devices due to their higher sensitivity, simplicity, robustness, good reproducibility, low cost, accurate and faster time responses [7, 8]. Electrochemical biosensors utilize amperometric, potentiometric, impedance and conductometric approaches to detect electrochemical 336 changes during biorecognition event in glucose sensing. Enzymatic amperometric glucose biosensors are the most widely used sensors whose principle is based on monitoring current generated by electrons exchange between biological systems and electrodes [8].

Extensive scientific contributions have been made in the development of enzymatic electrochemical glucose sensors, through three generations. In the first generation, enzymatic glucose biosensor used oxygen $(\mathrm{O} 2)$ as a mediator. The glucose level is estimated from the amperometric signal generated via electrochemical oxidation of hydrogen peroxide $(\mathrm{H} 2 \mathrm{O} 2)$ or electrochemical reduction of $\mathrm{O} 2$ [5]. An amperometric measurement of $\mathrm{H} 2 \mathrm{O} 2$ requires high potential for high selectivity and oxygen deficit 
occurs due to variations in oxygen tension and lower concentration which forced an evolution of second generation enzyme based biosensors [9, 10]. Here, oxygen was replaced by non-physiological electronredox mediator where the amperometric signal generated via oxidation of the mediator is used to estimate glucose levels [5, 9]. Redox-mediated glucose biosensor faced problems in maintaining mediator and enzyme near the electrode due to small and diffusive molecules [11].The third generation enzymatic electrochemical biosensors do not require mediator where electrons are directly transferred between enzymes and electrodes [11]. Recent advances in nanostructures and nanotubes such as graphene and carbon nanotubes are promising for the development of nano electrodes and enzymatic electrochemical nano sensors used to develop convenient blood glucose monitors [12-14]. Enzymatic electrochemical biosensors are characterized by shorter stability; relatively higher fabrication costs, complicated modification and limitations associated with the nature of enzymes such as irreversibility, and signal drift $[6,15,16]$. Table 1 provides a summary of few commercially available enzyme based electrochemical glucose monitors.

Table 1 Few commercially available glucose monitors based on enzymatic electrochemical biosensors

\begin{tabular}{|c|c|c|c|c|}
\hline Brand name & Enzyme & Mediator & Test time $(\mathrm{S})$ & Sample volume $(\mu \mathrm{L})$ \\
\hline Abbott Freestyle $\AA$ Lite & GDH-FAD(2) & Os complex & 5 & 0.3 \\
\hline Accu-Chek®Aviva Plus & GDH & Ferricyanide & 5 & 0.6 \\
\hline LifeScan OneTouch $®$ Ultra 2 & GOx & Ferricyanide & 5 & 1 \\
\hline Bayer Contour ${ }^{\mathrm{TM}}$ Next USB & GDH & Ferricyanide & 5 & 0.6 \\
\hline Precision Xtra ${ }^{\mathrm{TM}}$ & GDH & Ferricyanide & 5 & 0.6 \\
\hline
\end{tabular}

2.2Non-enzymatic electrochemical sensing

Non-enzymatic electrochemical sensors bring the beginning of the fourth generation of glucose biosensors [5]. The method involves direct oxidation of glucose into gluconic acid at enzyme-less solid electrodes [9]. These electrodes possess a higher surface area and electro catalytic activity with better sensitivity and selectivity over enzymatic glucose sensors. The trends towards the development of nonenzymatic glucose electrodes based on metals and their composites, alloys, and bimetals, metal-metallic oxides, carbon materials, and layered double hydroxides were reviewed in [17]. The study of nanomaterial for non-enzymatic glucose sensors was illustrated [18] and details on recent advances in nonenzymatic glucose sensors were described in [3].

The fabrication of non-enzymatic glucose sensor using copper oxide nanowires ( $\mathrm{CuO}$ NWs) as in [19] and copper nanowires with multi-walled carbon nanotubes [20] that provided high sensitivity, and fast response time $[19,20]$ were studied. The development of surfactant template assisted platinum nanoparticles (PtNPs) glucose biosensor [21], Ni/multi-walled carbon nanotubes (MWNTs) electrodes [22], graphene-Schottky junction based glucose biosensor [15], $\mathrm{Ni}_{3} \mathrm{~S}_{2}$ nanosheet array glucose electrodes [23], Copper nanoparticle modified graphene sheets electrode for novel non-enzyme glucose biosensors [24], and hollow $\mathrm{Co}_{3} \mathrm{O}_{4}$ microsphere assembled with nanocrystals non-enzymatic biosensor [25] were reported in research publications indicating the possibilities of their commercialization.

The advancements in nanotechnologies, such as nanomaterial, nano porous metals, carbon nanotubes and graphene allowed the developments of nonenzymatic glucose biosensors with higher surface areas, higher sensitivity, and better selectivity $[5,18]$. Despite the great efforts in scientific publications, commercialization of non-enzymatic biosensors have been a challenging issue. Non-enzymatic glucose sensors hardly catalyse glucose oxidation under normal physiological conditions and lack a perfect match between normal concentrations with analytical ranges of the fabricated sensor, which is difficult for clinical uses $[17,18]$.

\section{Non-invasive blood glucose monitoring techniques}

3.10ptical methods

Optical glucose sensing is the most widely studied method, for the development of non-invasive blood glucose measurement. Even though none of the optical based biosensors that meet clinical accuracy are commercialized yet, several researches are undergoing. The Table 2 below provides a brief summary of extensively studied optical based blood glucose monitoring techniques in recent years. 
Table 2 Summary of recent advances in optical based blood glucose monitoring techniques

\begin{tabular}{|c|c|}
\hline Optical technique & Descriptions of principles \\
\hline $\begin{array}{l}\text { Fluorescence } \\
\text { spectroscopy }\end{array}$ & $\begin{array}{l}\text { Depends on fluorescence where an irradiation of a substance with lower wavelength ultraviolet light } \\
\text { source results in an emission of light with different energy and frequency [26-28]. It contains a chemical } \\
\text { compound called fluorophores, a component that causes a molecule to absorb the energy of a specific } \\
\text { wavelength light and re-emit different energy at specific wavelengths where a change in fluorescence is } \\
\text { proportional to glucose concentration [29]. }\end{array}$ \\
\hline Raman spectroscopy & $\begin{array}{l}\text { Based on an inelastic scattering of laser light passed through human tissue which shifts its frequency and } \\
\text { changes wavelength through Raman effect [1]. The shift in frequency is used to observe vibrational, } \\
\text { rotational and low-frequency transitions. Molecular vibration affects an emission of scattered light which } \\
\text { is used to estimate the concentration of glucose [30]. }\end{array}$ \\
\hline $\begin{array}{l}\text { Photoacoustic } \\
\text { spectroscopy }\end{array}$ & $\begin{array}{l}\text { Measures an acoustic pressure wave produced by an interaction of laser light with tissues. An excitation } \\
\text { energy of infrared laser passes through the aqueous glucose solution, where it absorbs light and releases } \\
\text { heat energy [31]. This causes volumetric expansion in the light illuminated cylindrical region, generating } \\
\text { photoacoustic pressure wave correlated with glucose level }[31,32] \text {. }\end{array}$ \\
\hline $\begin{array}{l}\text { Absorption } \\
\text { spectroscopy }\end{array}$ & $\begin{array}{l}\text { Based on absorption, reflection and scattering properties of light by passing infrared light through human } \\
\text { tissue with wavelength ranges of near infrared }(750 \mathrm{~nm}-2500 \mathrm{~nm}) \text {, mid-infrared }(2500 \mathrm{~nm}-100,000 \mathrm{~nm}) \text {, or } \\
\text { far infrared. The light-tissue interaction produces absorption, reflection, and scattering of the irradiated } \\
\text { light source [31,33]. The change in light characteristics correlates with glucose concentration [34]. }\end{array}$ \\
\hline $\begin{array}{l}\text { Thermal emission } \\
\text { spectroscopy }\end{array}$ & $\begin{array}{l}\text { Employs a principle of tympanic membrane thermometers that measure signals of emitted infrared light } \\
\text { produced in human tissues due to changes in the concentration of blood glucose }[34,35] \text {. }\end{array}$ \\
\hline $\begin{array}{l}\text { Optical coherence } \\
\text { tomography }\end{array}$ & $\begin{array}{l}\text { Utilizes low coherent light source to measure optically scattered signal from human tissue. It involves a } \\
\text { combination of backscattered light from tissue with light reflected from the reference arm of the } \\
\text { interferometer. The delay correlation between backscattered light from the sample and light reflected } \\
\text { from reference arm are measured [30]. An increase in glucose concentration increases the refractive index } \\
\text { and causes a change in scattering of light [34]. }\end{array}$ \\
\hline Polarimetry & $\begin{array}{l}\text { Measures rotation of polarized light as it passes through optically active solutes such as glucose. The } \\
\text { polarization of light is dependent on thickness, temperature, and concentration of solutes which is used to } \\
\text { determine glucose levels in the blood. It was employed in aqueous humor of the eye [36]. }\end{array}$ \\
\hline Ocular spectroscopy & $\begin{array}{l}\text { Employs electrochemical biosensor based contact lens to measure glucose concentration in tears }[34,37] \text {. } \\
\text { A change in wavelength of reflected light determines glucose concentration [38]. }\end{array}$ \\
\hline $\begin{array}{l}\text { Occlusion } \\
\text { spectroscopy }\end{array}$ & $\begin{array}{l}\text { Measures the scattering property of red or near-infrared light passed through a human finger after } \\
\text { applying pressure that occludes blood flow }[1,39] \text {. }\end{array}$ \\
\hline $\begin{array}{l}\text { Metabolic } \\
\text { Heat Conformation }\end{array}$ & $\begin{array}{l}\text { Involves multivariate mathematical analysis of heat dissipation, the rate of blood flow and degree of } \\
\text { oxygen saturation in blood where an oxidation of glucose generates heat whose quantity is correlated } \\
\text { with the amount of dissipative oxygen and glucose [40]. It uses humidity, thermal and optical sensors } \\
\text { [41]. }\end{array}$ \\
\hline $\begin{array}{l}\text { Conservation } \\
\text { Energy }\end{array}$ & $\begin{array}{l}\text { It is an extension of metabolic heat conformation that additionally measures basal metabolic rates and } \\
\text { heart rates [42]. }\end{array}$ \\
\hline
\end{tabular}

In the Table 3 below, the advantages and limitations of optical based blood glucose monitoring techniques are described.

Table 3 Summary of advantages and drawbacks of optical based blood glucose sensors

\begin{tabular}{lll}
\hline Optical technique & Merits & Limitations \\
\hline $\begin{array}{l}\text { Fluorescence } \\
\text { spectroscopy }\end{array}$ & $\begin{array}{l}\text { Extremely sensitive and requires less } \\
\text { calibration [27]. }\end{array}$ & $\begin{array}{l}\text { Depends on skin colour, thickness, and pigmentation. The } \\
\text { fluorophore dye may cause toxicity to tissues [1, 27]. }\end{array}$ \\
\hline Raman spectroscopy & $\begin{array}{l}\text { Less sensitive to temperature, water, and } \\
\text { interference from other light sources } \\
{[30] .}\end{array}$ & $\begin{array}{l}\text { Instability of laser source, poor signal to noise ratio, and } \\
\text { longer spectral acquisition time are major drawbacks [30,33]. }\end{array}$ \\
\hline $\begin{array}{l}\text { Photoacoustic } \\
\text { spectroscopy }\end{array}$ & $\begin{array}{l}\text { Has a higher sensitivity [30], and wide } \\
\text { wavelength range laser light from } \\
\text { Ultraviolet to NIR. }\end{array}$ & $\begin{array}{l}\text { Sensitive to environmental factors. Susceptible to } \\
\text { interferences from physiological substances [33]. }\end{array}$ \\
\hline $\begin{array}{l}\text { Absorption } \\
\text { spectroscopy }\end{array}$ & $\begin{array}{l}\text { Less expensive. Possesses good tissue } \\
\text { penetration property [34]. }\end{array}$ & $\begin{array}{l}\text { Sensitive to environmental factors. Has poor signal to noise } \\
\text { ratio (SNR) and affected by tissue compositions [34]. }\end{array}$ \\
\hline
\end{tabular}




\begin{tabular}{lll}
\hline Optical technique & Merits & Limitations \\
\hline $\begin{array}{l}\text { Thermal emission } \\
\text { spectroscopy }\end{array}$ & $\begin{array}{l}\text { Requires less calibration. Has good } \\
\text { reproducibility [34,35]. }\end{array}$ & $\begin{array}{l}\text { Has poor accuracy. Affected by temperature, movement, and } \\
\text { thickness of tissue [35]. }\end{array}$ \\
\hline $\begin{array}{l}\text { Optical coherence } \\
\text { tomography }\end{array}$ & $\begin{array}{l}\text { Characterized by good SNR, high } \\
\text { resolution, and high penetration. }\end{array}$ & Sensitive to motion and skin temperature. \\
\hline Polarimetry & $\begin{array}{l}\text { Independent of temperature and PH } \\
\text { variations. Easy for miniaturization. }\end{array}$ & $\begin{array}{l}\text { Sensitive to scattering of tissues, and motion. Has poor } \\
\text { specificity to glucose molecules. }\end{array}$ \\
\hline Ocular spectroscopy & $\begin{array}{l}\text { Performed at eye cornea where a } \\
\text { scattering of light is low [38]. }\end{array}$ & $\begin{array}{l}\text { There is a time lag between glucose in blood and tear. The } \\
\text { lens is uncomfortable for people with diabetes. }\end{array}$ \\
\hline $\begin{array}{l}\text { Occlusion } \\
\text { spectroscopy }\end{array}$ & Has a good signal to noise ratio. & Requires compensation for signal drift [1]. \\
\hline $\begin{array}{l}\text { Metabolic } \\
\text { Heat Conformation }\end{array}$ & Feasible and less expensive. & Suffers from environmental interference. \\
\hline $\begin{array}{l}\text { Conservation of } \\
\text { Energy }\end{array}$ & $\begin{array}{l}\text { Has good glucose correlation coefficient } \\
\text { [42]. }\end{array}$ & Affected by environmental variations. \\
\hline
\end{tabular}

\subsection{Electromagnetic method}

Electromagnetic sensing involves measurement of blood's dielectric properties detected through changes in eddy currents using electromagnetic coupling between two inductors [43]. The change in blood glucose concentration results in the variation of blood's dielectric properties such as permittivity and conductivity [44]. This causes changes in the electromagnetic coupling of nearby inductors affecting their impedances which results in variations in resonant frequency. The variations in frequency shift helps to determine blood's dielectric properties correlated with the concentration of glucose $[43,45]$. It involves an application of a signal with a specified frequency at primary inductor and measuring an output from the secondary inductor [35, 43]. This method does not require ionization of substances in the body, and utilization of specified frequency range signal helps suppress interference from biological components in the tissues [30].

The feasibility of electromagnetic sensing for noninvasive blood glucose monitoring was demonstrated in research papers. An electromagnetic non-invasive blood glucose measurement with preliminary results based on a small frequency band of $45 \mathrm{MHz}$ was studied in [43]. Ultra-wideband (UWB) microwave blood glucose detection technique using $6.5 \mathrm{GHz}$ signal was proposed by [46] where experimental measurements were performed using realistic earlobe phantom with blood glucose range of $0 \mathrm{mg} / \mathrm{dl}-400$ $\mathrm{mg} / \mathrm{dl}$. UWB imaging with a signal having a center frequency of $4.7 \mathrm{GHz}$ was used to measure glucose concentration in blood plasma, which exhibited an accuracy of $81 \%$ [47]. The design of novel and miniaturized microwave based non-invasive blood glucose monitoring was proposed in [48-50]. Susceptibility of optimal frequency investigation to the temperature and the dependence of dielectric parameters on other components of blood are the main drawbacks of this technique [51].

\subsection{Bioimpedance spectroscopy}

This technique is based on the measurement of impedance as a function of frequency in response to low-intensity current applied across tissue [52, 53]. The change in plasma's glucose concentration causes an increase in potassium ion concentration and a decrease in sodium ion concentration in red blood cells [54] which eventually results in variations of membrane potential. This variation can be estimated by determining permittivity and conductivity of cell membrane through the dielectric spectrum [52, 55]. Bioimpedance spectroscopy based blood glucose measurement on the human tissue was experimentally demonstrated by [52] which was done by measuring the impedance between frequency ranges of $1 \mathrm{MHz}$ and $200 \mathrm{MHz}$ to suppress sensitivity of glucose sensor to body's electrical changes. The design of bioimpedance spectroscopy based noninvasive wearable blood glucose monitor was studied [56]. This method is susceptible to temperature, movement, skin moisture, sweating, and body dehydration.

\subsection{Reverse iontophoresis}

This method uses low electrical current across the skin to withdraw a small amount of glucose with electrochemical glucose sensors worn on the skin. Then electrochemical sensors determine the levels of glucose in the blood [33, 57].

Development of tattoo-based non-invasive glucose sensor with reverse iontophoresis was indicated in [58]. Reverse iontophoresis requires finger prick for periodic calibration, causes skin irritation, has poor accuracy, and environmental variations $[1,59]$. 


\subsection{Ultrasound}

The low-frequency ultrasound wave is applied across the skin to extract concentration of glucose determined by an electrochemical amperometric biosensor or optical sensor. The feasibility of an amperometric biosensor placed over ultrasonically permeated sites was evaluated by [60]. The drawback of this technique is associated with an amount of extracted glucose concentration. Ultrasound enhances the permeability of skin which extracts only minute volume of glucose. Table 4 provides summary of few non-invasive blood glucose monitors which are based on transdermal and optical methods.

Table 4 Summary of transdermal non-invasive blood glucose devices

\begin{tabular}{|c|c|c|c|}
\hline Techniques & Device description & Target site & Approvals and status \\
\hline $\begin{array}{l}\text { Bioimpedance } \\
\text { spectroscopy }\end{array}$ & $\begin{array}{l}\text { Pendragon Medical Ltd, } \\
\text { Switzerland: Pendra } \odot\end{array}$ & Wrist skin & $\begin{array}{l}\text { CE approved in 2003; withdrawn from the market } \\
\text { due to poor accuracy in the post-marketing } \\
\text { validation study. }\end{array}$ \\
\hline $\begin{array}{l}\text { Ultrasound, } \\
\text { Electromagnetic } \\
\text { and Heat capacity }\end{array}$ & $\begin{array}{l}\text { Integrity Applications, Inc., } \\
\text { Israel: GlucoTrack }\end{array}$ & Earlobe skin & $\begin{array}{l}\text { CE Approved in 2013; claims market availability } \\
\text { in few countries [61]. }\end{array}$ \\
\hline $\begin{array}{l}\text { Radio wave } \\
\text { Spectroscopy }\end{array}$ & $\begin{array}{l}\text { MediWise Ltd., London, United } \\
\text { Kingdom (UK): Glucowise }\end{array}$ & $\begin{array}{l}\text { Skin area } \\
\text { between thumb } \\
\text { and forefinger } \\
\text { or earlobe }\end{array}$ & $\begin{array}{l}\text { It is under development. The company plans to } \\
\text { launch in late } 2018 \text {. }\end{array}$ \\
\hline \multirow[t]{2}{*}{$\begin{array}{l}\text { Reverse } \\
\text { iontophoresis }\end{array}$} & $\begin{array}{l}\text { Animas Technologies LLC: } \\
\text { GlucoWatch@ } @ 2 \text { Biographer }\end{array}$ & Wrist skin & $\begin{array}{l}\mathrm{CE} \text { and FDA approved; withdrawn from the } \\
\text { market due to poor accuracy and skin irritation in } \\
2007 \text {. }\end{array}$ \\
\hline & $\begin{array}{l}\text { Nemaura Medical Inc., UK: } \\
\text { SugarBeat }^{\mathrm{TM}}\end{array}$ & $\begin{array}{ll}\text { Leg, } & \text { Arm } \\
\text { Abdomen } & \\
\end{array}$ & $\begin{array}{l}\text { CE approved in 2016; the company plans to begin } \\
\text { its initial launch in the UK due mid- } 2018 \text {. }\end{array}$ \\
\hline $\begin{array}{l}\text { Raman } \\
\text { spectroscopy }\end{array}$ & C8 Medisensors, USA & Abdomen skin & $\begin{array}{l}\text { CE approved in } 2011 \text {; the company was closed } \\
\text { due to financial problems. }\end{array}$ \\
\hline $\begin{array}{l}\text { Near -infrared } \\
\text { spectroscopy }\end{array}$ & $\begin{array}{l}\text { Cnoga Medical, Israel: } \\
\text { TensorTip Combo Glucometer } \\
(\mathrm{COG})\end{array}$ & Fingertip skin & $\begin{array}{l}\text { CE approved in } 2014 \text {. The post-market evaluation } \\
\text { indicated high correlation with reference to } \\
\text { invasive devices }[62,63] \text {. }\end{array}$ \\
\hline
\end{tabular}

\section{Major challenges in blood glucose monitoring techniques}

Despite great achievements and improvements in the development of blood glucose monitors, several challenges still persist. An invasiveness of currently available glucose monitors decreases user's compliance, may cause infections, irritation, skin puncture and reduce the frequency of use.

Accuracy is a major challenge in developing blood glucose biosensors. A system accuracy of CE approved invasive blood glucose monitors was evaluated where some devices failed to meet minimum accuracy requirements of DIN EN ISO 15197:2003 and ISO 15197:2013 standards [64, 65]. Most of CE approved non-invasive blood glucose monitors do not meet these standards.

The periodic recalibrations of glucose monitors is another challenging factor. Most of the non-invasive blood glucose monitoring techniques need withdrawal of blood samples and follow complex procedures to calibrate glucose measurement results prior to use [59]. Blood glucose monitors requiring invasive capillary calibration are associated with an increase in cost, discomfort, inconvenience, and complex procedures $[9,66]$.

Poor signal to noise ratio is another challenging factor in detection and development of non-invasive glucose sensors. Non-invasive glucose monitors lack good linearity, sensitivity, and specificity to glucose molecules, which weakens the signal and an accuracy of glucose estimation. Portability, complexity, reliability, durability, cost effectiveness, and user experience are also determinant parameters in the development of blood glucose monitors.

\section{Future perspectives of non-invasive blood glucose monitoring}

The growing advances in nanotechnology and biomaterials will transform the future of non-invasive blood glucose monitoring [67]. Glucose biosensors based on nanometals, polymer nanocomposites, carbon nanotubes and graphene are being studied $[12-15,19,20,22]$; which are promising for the development of portable and convenient painless blood glucose monitors. 
Multi-sensing can improve the signal to noise ratio for an estimation of glucose concentration. This was indicated in GlucoTrack ${ }^{\circledR}$ which utilized three noninvasive detection methods; electromagnetic, thermal and ultrasonic [59]. Researchers indicated that multisensing integrated with proper estimation algorithm enhances accuracy, improves glucose prediction performance, and reduces time delays in measurement [68-73].

Employing appropriate glucose estimation algorithms and self-calibration models improve calibration required in blood glucose monitors. Partial leastsquare regression (PLS) and radial basis function (RBF) [74, 75], artificial neural networks (ANN) [76, 77], and pseudo-linear regression with ARMAX model [78, 79], were a few calibration models used for estimation of glucose levels in non-invasive glucose monitors. For instance, FDA has approved calibration free Abbot's Freestyle Libre Pro $^{\mathrm{TM}}$ and Dexcom $^{\mathrm{TM}}$ G6 blood glucose monitors. Dexcom ${ }^{\mathrm{TM}}$ G6 was launched on June 4, 2018.

\section{Conclusion}

Through rigorous studies and scientific breakthroughs, sensing and monitoring of blood glucose levels are getting better and more convenient. The trends of recent progress in nanotechnology and miniaturization of biosensors enabled the development of reliable, more accurate, and comprehensive glucose monitoring devices.

Despite the remarkable advances and achievements in the blood glucose monitoring technologies, there are still challenges in the development of noninvasive glucose monitors. Due to lack of precision and clinically acceptable accuracy, non-invasive blood glucose biosensors have never achieved the requirements for market commercialization. There is a high market demand for calibration-free noninvasive blood glucose monitors. To meet this need, an elegant and ingenious technological innovation is highly appreciated for the future development and commercialization of reliable, convenient, clinically accurate, and pain-free blood glucose monitors.

\section{Acknowledgment}

None.

\section{Conflicts of interest}

The authors have no conflicts of interest to declare.
References

[1] Nawaz A, Øhlckers P, Sælid S, Jacobsen M, Akram MN. Non-invasive continuous blood glucose measurement techniques. Journal of Bioinformatics and Diabetes. 2016; 1(3):1-27.

[2] Yadav J, Rani A, Singh V, Murari BM. Prospects and limitations of non-invasive blood glucose monitoring using near-infrared spectroscopy. Biomedical Signal Processing and Control. 2015; 18:214-27.

[3] Tian K, Prestgard M, Tiwari A. A review of recent advances in nonenzymatic glucose sensors. Materials Science and Engineering: C. 2014; 41:100-18.

[4] Vashist SK, Zheng D, Al-Rubeaan K, Luong JH, Sheu FS. Technology behind commercial devices for blood glucose monitoring in diabetes management: a review. Analytica Chimica Acta. 2011; 703(2):124-36.

[5] Toghill KE, Compton RG. Electrochemical nonenzymatic glucose sensors: a perspective and an evaluation. International Journal of Electrochemical Science. 2010; 5:1246-301.

[6] Lee H, Hong YJ, Baik S, Hyeon T, Kim DH. Enzymebased glucose sensor: from invasive to wearable device. Advanced Healthcare Materials. 2018; 7(8):114.

[7] Hammond JL, Formisano N, Estrela P, Carrara S, Tkac J. Electrochemical biosensors and nanobiosensors. Essays in Biochemistry. 2016; 60(1):69-80.

[8] Yoo EH, Lee SY. Glucose biosensors: an overview of use in clinical practice. Sensors. 2010; 10(5):4558-76.

[9] Vaddiraju S, Burgess DJ, Tomazos I, Jain FC, Papadimitrakopoulos F. Technologies for continuous glucose monitoring: current problems and future promises. Journal of Diabetes Science and Technology. 2010; 4(6):1540-62.

[10] Niraj GM, Varshney H, Pandey S, Singh S. Sensors for diabetes:glucose biosensors by using different newer techniques: a review. International Journal of Therapeutic Applications. 2012; 6:28-37.

[11] Bruen D, Delaney C, Florea L, Diamond D. Glucose sensing for diabetes monitoring: recent developments. Sensors. 2017; 17(8):1:21.

[12] Ghoreishizadeh SS, Zhang X, Sharma S, Georgiou P. Study of electrochemical impedance of a continuous glucose monitoring sensor and its correlation with sensor performance. IEEE Sensors Letters. 2018; 2(1):1-4.

[13] Yoon HS, Jeong SK, Xuan X, Park JY. Semiimplantable polyimide/PTFE needle-shaped biosensor for continuous glucose monitoring. In international conference on solid-state sensors, actuators and microsystems 2017 (pp. 1714-7). IEEE.

[14] Mikoliunaite L, Geceviciute M, Voronovic J, Paklonskaite I, Ramanaviciene JB, Ramanavicius A. Carbon nanostructures for electrochemical sensors. In international conference on nanomaterials: application $\&$ properties 2017. IEEE. 
[15] Sakr MA, Serry M. Non-enzymatic graphene-based biosensors for continous glucose monitoring. In SENSORS 2015 (pp. 1-4). IEEE.

[16] Zhu C, Yang G, Li H, Du D, Lin Y. Electrochemical sensors and biosensors based on nanomaterials and nanostructures. Analytical Chemistry. 2014; 87(1):230-49.

[17] Wang G, He X, Wang L, Gu A, Huang Y, Fang B, et al. Non-enzymatic electrochemical sensing of glucose. Microchimica Acta. 2013; 180(3-4):161-86.

[18] Si P, Huang Y, Wang T, Ma J. Nanomaterials for electrochemical non-enzymatic glucose biosensors. RSC Advances. 2013; 3(11):3487-502.

[19] Zhang Y, Liu Y, Su L, Zhang Z, Huo D, Hou C, et al. $\mathrm{CuO}$ nanowires based sensitive and selective nonenzymatic glucose detection. Sensors and Actuators B: Chemical. 2014; 191:86-93.

[20] Huang J, Dong Z, Li Y, Li J, Wang J, Yang H, et al. High performance non-enzymatic glucose biosensor based on copper nanowires-carbon nanotubes hybrid for intracellular glucose study. Sensors and Actuators B: Chemical. 2013; 182:618-24.

[21] Hossain MF, Barman SC, Park JY. A highly performed nonenzymatic glucose sensor using surfactant template assisted platinum nanoparticles. In international conference on solid-state sensors, actuators and microsystems 2017 (pp. 1584-7). IEEE.

[22] Zhang X, Wang G, Huang Y, Yu L, Fang B. Nonenzymatic glucose detection using $\mathrm{Ni} /$ multi-walled carbon nanotubes composite. Micro \& Nano Letters. 2012; 7(2):168-70.

[23] Huo H, Zhao Y, Xu C. 3D Ni 3 S 2 nanosheet arrays supported on $\mathrm{Ni}$ foam for high-performance supercapacitor and non-enzymatic glucose detection. Journal of Materials Chemistry A. 2014; 2(36):151117.

[24] Luo J, Jiang S, Zhang H, Jiang J, Liu X. A novel nonenzymatic glucose sensor based on $\mathrm{Cu}$ nanoparticle modified graphene sheets electrode. Analytica Chimica Acta. 2012; 709:47-53.

[25] Yin H, He X, Cui Z, Nie Q. Hollow Co3O4 microspheres assembled with nanocrystals for nonenzymatic glucose sensor. Micro \& Nano Letters. 2016; 11(3):151-5.

[26] Klonoff DC. Overview of fluorescence glucose sensing: a technology with a bright future. Journal of Diabetes Science and Technology. 2012; 6(6):124250.

[27] Hull EL, Matter NI, Olson BP, Ediger MN, Magee AJ, Way JF, et al. Noninvasive skin fluorescence spectroscopy for detection of abnormal glucose tolerance. Journal of Clinical \& Translational Endocrinology. 2014; 1(3):92-9.

[28] Stirban A. Noninvasive skin fluorescence spectroscopy for diabetes screening. Journal of Diabetes Science and Technology. 2013; 7(4):1001-4.

[29] Pickup JC, Khan F, Zhi ZL, Coulter J, Birch DJ. Fluorescence intensity-and lifetime-based glucose sensing using glucose/galactose-binding protein.
Journal of Diabetes Science and Technology. 2013; 7(1):62-71.

[30] So CF, Choi KS, Wong TK, Chung JW. Recent advances in noninvasive glucose monitoring. Medical Devices (Auckland, NZ). 2012; 5:45-52.

[31] Pai PP, Sanki PK, Sahoo SK, De A, Bhattacharya S, Banerjee S. Cloud computing-based non-invasive glucose monitoring for diabetic care. IEEE Transactions on Circuits and Systems I: Regular Papers. 2018; 65(2):663-76.

[32] Al Naam HA, Idrees MO, Awad A, Abdalsalam OS, Mohamed F. Noninvasive blood glucose measurement based on photo-acoustic spectroscopy. In international conference on computing, control, networking, electronics and embedded systems engineering 2015 (pp. 1-4). IEEE.

[33] Vashist SK. Non-invasive glucose monitoring technology in diabetes management: a review. Analytica Chimica Acta. 2012; 750:16-27.

[34] Haxha S, Jhoja J. Optical based noninvasive glucose monitoring sensor prototype. IEEE Photonics Journal. 2016; 8(6):1-11.

[35] Losoya-Leal A, Camacho-León S, Dieck-Assad G, Martínez-Chapa SO. State of the art and new perspectives in non-invasive glucose sensors. Revista Mexicana De Ingeniería Biomédica. 2012; 33(1):4152.

[36] Ansari RR, Boeckle S, Rovati LL. New optical scheme for a polarimetric-based glucose sensor. Journal of Biomedical Optics. 2004; 9(1):103-16.

[37] Romeo A, Moya A, Leung TS, Gabriel G, Villa R, Sánchez S. Inkjet printed flexible non-enzymatic glucose sensor for tear fluid analysis. Applied Materials Today. 2018; 10:133-41.

[38] Chowdhury MK, Srivastava A, Sharma N, Sharma S. Challenges \& countermeasures in optical noninvasive blood glucose detection. International Journal of Innovative Research in Science, Engineering and Technology. 2013; 2(1):329-34.

[39] Amir O, Weinstein D, Zilberman S, Less M, PerlTreves D, Primack H, et al. Continuous noninvasive glucose monitoring technology based on "occlusion spectroscopy". Journal of Diabetes Science and Technology. 2007; 1(4):463-9.

[40] Tang F, Wang X, Wang D, Li J. Non-invasive glucose measurement by use of metabolic heat conformation method. Sensors. 2008; 8(5):3335-44.

[41] Jang S, Xu C. Review of emerging approaches in nonor minimally invasive glucose monitoring and their application to physiological human body fluids. International Journal of Biosensors \& Bioelectronics. 2018; 4(1):5-9.

[42] Zhang Y, Zhu JM, Liang YB, Chen HB, Yin SM, Chen ZC. Non-invasive blood glucose detection system based on conservation of energy method. Physiological Measurement. 2017; 38(2):325-42.

[43] Alavi SM, Gourzi M, Rouane A, Nadi M. An original method for non-invasive glucose measurement: preliminary results. In proceedings of the international 
conference of the engineering in medicine and biology society 2001 (pp. 3318-20). IEEE.

[44] Tura A, Sbrignadello S, Barison S, Conti S, Pacini G. Impedance spectroscopy of solutions at physiological glucose concentrations. Biophysical Chemistry. 2007; 129(2-3):235-41.

[45] Sen K, Anand S. Design of microstrip sensor for noninvasive blood glucose monitoring. In international conference on emerging trends \& innovation in ICT 2017 (pp. 5-8). IEEE.

[46] Xiao X, Li Q. A non-invasive measurement of blood glucose concentration by UWB microwave spectrum. IEEE Antennas and Wireless Propagation Letters. 2017; 16:1040-3.

[47] Ali MS, Shoumy NJ, Khatun S, Kamarudin LM, Vijayasarveswari V. Non-invasive blood glucose measurement performance analysis through UWB imaging. In international conference on electronic design 2016 (pp. 513-6). IEEE.

[48] Hofmann M, Bloss M, Weigel R, Fischer G, Kissinger D. Non-invasive glucose monitoring using open electromagnetic waveguides. In European microwave conference 2012 (pp. 546-9). IEEE.

[49] Turgul V, Kale I. A novel pressure sensing circuit for non-invasive $\mathrm{RF} /$ microwave blood glucose sensors. In mediterranean microwave symposium 2016 (pp. 1-4). IEEE.

[50] Shao J, Yang F, Xia F, Zhang Q, Chen Y. A novel miniature spiral sensor for non-invasive blood glucose monitoring. In European conference on antennas and propagation 2016 (pp. 1-2). IEEE.

[51] Tura A, Maran A, Pacini G. Non-invasive glucose monitoring: assessment of technologies and devices according to quantitative criteria. Diabetes Research and Clinical Practice. 2007; 77(1):16-40.

[52] Caduff A, Dewarrat F, Talary M, Stalder G, Heinemann L, Feldman Y. Non-invasive glucose monitoring in patients with diabetes: a novel system based on impedance spectroscopy. Biosensors and Bioelectronics. 2006; 22(5):598-604.

[53] Narasimham S, Kaila G, Anand S. Non-invasive glucose monitoring using impedance spectroscopy. International Journal of Biomedical Engineering and Technology. 2014; 14(3):225-32.

[54] Hillier TA, Abbott RD, Barrett EJ. Hyponatremia: evaluating the correction factor for hyperglycemia. The American Journal of Medicine. 1999; 106(4):399 403.

[55] Polevaya Y, Ermolina I, Schlesinger M, Ginzburg BZ, Feldman Y. Time domain dielectric spectroscopy study of human cells: II. normal and malignant white blood cells. Biochimica Biophysica Acta (BBA)Biomembranes. 1999; 1419(2):257-71.

[56] Liu Y, Xia M, Nie Z, Li J, Zeng Y, Wang L. In vivo wearable non-invasive glucose monitoring based on dielectric spectroscopy. In international conference on signal processing 2016 (pp. 1388-91). IEEE.

[57] Tamada JA, Bohannon NJ, Potts RO. Measurement of glucose in diabetic subjects using noninvasive transdermal extraction. Nature Medicine. 1995; 1(11):1198-201.

[58] Bandodkar AJ, Jia W, Yardımcı C, Wang X, Ramirez J, Wang J. Tattoo-based noninvasive glucose monitoring: a proof-of-concept study. Analytical Chemistry. 2014; 87(1):394-8.

[59] Lin T, Gal A, Mayzel Y, Horman K, Bahartan K. Non-invasive glucose monitoring: a review of challenges and recent advances. Current Trends in Biomedical Engineering \& Biosciences. 2017; 6(5):18.

[60] Chuang H, Taylor E, Davison TW. Clinical evaluation of a continuous minimally invasive glucose flux sensor placed over ultrasonically permeated skin. Diabetes Technology \& Therapeutics. 2004; 6(1):2130.

[61] Lin T, Mayzel Y, Bahartan K. The accuracy of a noninvasive glucose monitoring device does not depend on clinical characteristics of people with type 2 diabetes mellitus. Journal of Drug Assessment. 2018; 7(1):1-7.

[62] Segman Y. Device and method for noninvasive glucose assessment. Journal of Diabetes Science and Technology. 2018.

[63] Pfützner A, Strobl S, Demircik F, Redert L, Pfützner J, Pfützner $\mathrm{AH}$, et al. Evaluation of a new noninvasive glucose monitoring device by means of standardized meal experiments. Journal of Diabetes Science and Technology. 2018.

[64] Freckmann G, Schmid C, Baumstark A, Pleus S, Link M, Haug C. System accuracy evaluation of 43 blood glucose monitoring systems for self-monitoring of blood glucose according to DIN EN ISO 15197. Journal of Diabetes Science and Technology. 2012; 6(5):1060-75.

[65] Freckmann G, Baumstark A, Jendrike N, Zschornack E, Kocher S, Tshiananga J, et al. System accuracy evaluation of 27 blood glucose monitoring systems according to DIN EN ISO 15197. Diabetes Technology \& Therapeutics. 2010; 12(3):221-31.

[66] Rodbard D. Continuous glucose monitoring: a review of successes, challenges, and opportunities. Diabetes Technology \& Therapeutics. 2016; 18(S2):3-13.

[67] Makaram P, Owens D, Aceros J. Trends in nanomaterial-based non-invasive diabetes sensing technologies. Diagnostics. 2014; 4(2):27-46.

[68] Sobel SI, Chomentowski PJ, Vyas N, Andre D, Toledo FG. Accuracy of a novel noninvasive multisensor technology to estimate glucose in diabetic subjects during dynamic conditions. Journal of Diabetes Science and Technology. 2014; 8(1):54-63.

[69] Xiong F, Hipszer BR, Joseph J, Kam M. Improved blood glucose estimation through multi-sensor fusion. In international conference of the engineering in medicine and biology society 2011 (pp. 377-80). IEEE.

[70] Yadav J, Rani A, Singh V, Murari BM. Investigations on multisensor-based noninvasive blood glucose measurement system. Journal of Medical Devices. 2017; 11(3). 
[71] Geng Z, Tang F, Ding Y, Li S, Wang X. Noninvasive continuous glucose monitoring using a multisensorbased glucometer and time series analysis. Scientific Reports. 2017; 7:1-10.

[72] Asaduzzaman A, Samadarsinee S, Chidella KK. Simulating multisensor noninvasive blood glucose monitoring systems. In Southeastcon 2016 (pp. 1-7). IEEE.

[73] Zanon M, Sparacino G, Facchinetti A, Talary MS, Mueller M, Caduff A, et al. Non-invasive continuous glucose monitoring with multi-sensor systems: a Monte Carlo-based methodology for assessing calibration robustness. Sensors. 2013; 13(6):7279-95.

[74] Fischbacher C, Jagemann KU, Danzer K, Müller UA, Papenkordt L, Schüler J. Enhancing calibration models for non-invasive near-infrared spectroscopical blood glucose determination. Fresenius' Journal of Analytical Chemistry. 1997; 359(1):78-82.

[75] Müller UA, Mertes B, Fischbacher C, Jageman KU, Danzer K. Non-invasive blood glucose monitoring by means of near infrared spectroscopy: methods for improving the reliability of the calibration models. The International Journal of Artificial Organs. 1997; 20(5):285-90.

[76] Ramasahayam S, Koppuravuri SH, Arora L, Chowdhury SR. Noninvasive blood glucose sensing using near infra-red spectroscopy and artificial neural networks based on inverse delayed function model of neuron. Journal of Medical Systems. $2015 ; 39$.

[77] Savage MB, Kun S, Harjunmaa H, Peura RA. Development of a non-invasive blood glucose monitor: application of artificial neural networks for signal processing. In proceedings of the bioengineering conference 2000 (pp. 29-30). IEEE.

[78] Stemmann M, Ståhl F, Lallemand J, Renard E, Johansson R. Sensor calibration models for a noninvasive blood glucose measurement sensor. In international conference of the engineering in medicine and biology society 2010 (pp. 4979-82). IEEE.

[79] Cinar A, Turksoy K. Modeling glucose and insulin concentration dynamics. In advances in artificial pancreas systems 2018 (pp. 33-50). Springer, Cham.

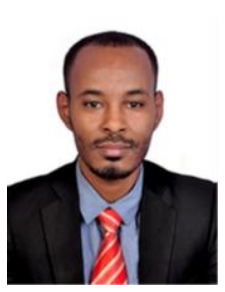

Tadesse Waktola Gamessa has received a Bachelor of Science degree in Biomedical Engineering from Jimma Institute of Technology, Jimma University, Ethiopia in July 2014. He has two years of work experience in Hospitals and Health Institutions as a Biomedical Engineer. He has worked as Biomedical Engineering Team Leader, Gandhi Memorial Hospital, Addis Ababa City Administration Health Bureau, Addis Ababa, Ethiopia. He has completed his Master of Engineering (M.E.) in Biomedical Engineering at University College of Engineering (A), Osmania University, Hyderabad, India. His research interests include Biomedical Imaging and Instrumentation, Biomedical Electronics, Biomedical Signal processing and Neural Engineering.

Email: waktolatadesse@yahoo.com

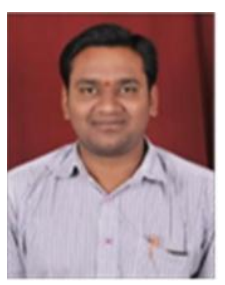

Dabbu Suman has obtained his Bachelor of Engineering and Master of Engineering in Bio Medical Engineering, from the Department of BME, University College of Engineering, Osmania University, Hyderabad, India. He has 13 years of teaching and 9 years of research experience in the field of Bio Signal Acquisition and Feature Extraction. Currently he is working as an Assistant Professor in the Department of BME, UCE (A), Osmania University, Hyderabad, India. He is also pursuing his Ph.D.

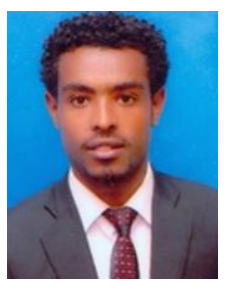

Zerihun Ketema Tadesse has received a Bachelor of Science degree in Biomedical Engineering from Jimma Institute of Technology, Jimma University, Ethiopia in July 2014. He has two years of work experience in Hospitals and Health Institutions as a Biomedical Engineer. He has worked as Biomedical Engineering Team Leader, Yekatit 12 Hospital Medical College, Addis Ababa City Administration Health Bureau, Addis Ababa, Ethiopia. He has completed his Master of Engineering (M.E.) in Biomedical Engineering at University College of Engineering (A), Osmania University, Hyderabad, India. His research interests are Biomedical Imaging and Instrumentation, Biomedical Electronics, Biomedical Signal processing and Neural Engineering. 